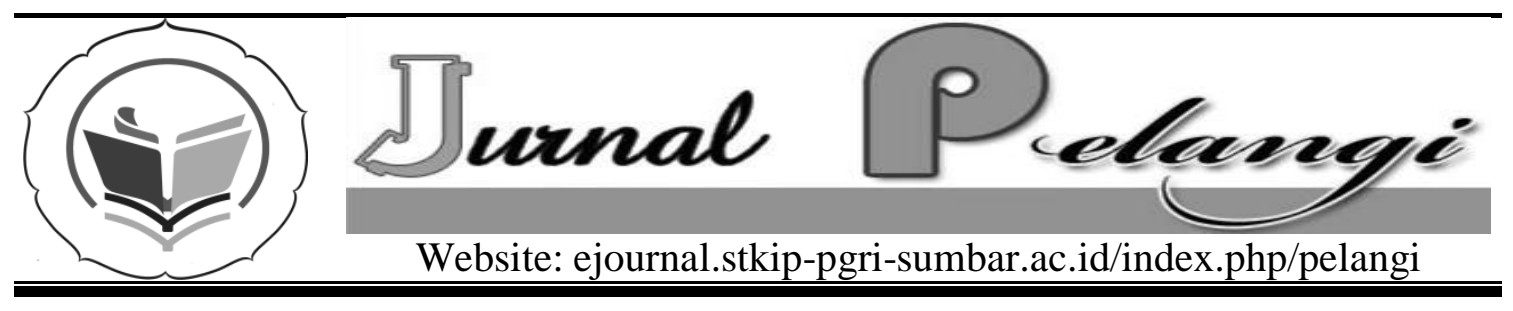

\title{
KONSENTRASI HAMBAT MINIMUM (KHM) EKSTRAK DAUN TEH (Camellia sinensis L.) PADA Escherichia coli DAN Salmonella sp.
}

\author{
Rina Widiana
}

STKIP PGRI Sumatera Barat

INFO ARTIKEL

\begin{tabular}{l} 
Diterima: \\
Direview: \\
Disetujui: \\
\hline
\end{tabular}

Keyword:

tea leaves, extract, diarrhea, Eschrichia coli, Salmonella sp., minimum restriction concentrate.

\section{PENDAHULUAN}

Diare merupakan penyebab kematian pada balita dan membunuh

\section{Abstrak}

Diarrhea is the condition loosing too much liquid and electrolyte through feces and it is second biggest cause of infant death in Indonesia. Diarrhea is caused by Salmonella sp and Escherichia coli bacteria. Inappropriate drug used such as anti diarrhea and antibiotic can cause another health problem. An alternative treatment which does not cause side effect to the diarrhea victim is using an anti microbe active of the plant medicine. One of the plant which is used by the people as a treatment for the diarrhea victim is tea leaves (Camellia sinensis L.). it contains anti microbe active such as catecin, tannin, flavonoid and saponin. Thus, the research was conducted to find out the minimum restriction concentrate of Camellia sinensis $L$. in E. coli and Salmonella $s p$. The minimum restriction concentration is used dilution method with jelly as the media (Jelly dilution method) by double it. The concentrations of $E$. coli are $50 \%, 25 \%, 12,5 \%, 6,25 \%, 3,125 \%$ and 1,56\% with $10 \%$ antibiotic ampicilin control. The concentrations for Salmonella sp are 50\%, $25 \%, 12,5 \%, 6,25 \%, 3,125 \%, 1,56$ $\%, 0,78 \%, 0,39 \%, 0,195 \%$ and 0,0975\%. The data was analyzed in qualitative method by examining the minimum restriction of tea leaves extract (Camellia sinensis L.) in the bacteria that caused diarrhea. The research was conducted on August 2010 in Biology Laboratory of STKIP PGRI West Sumatera. Tea leaves was extracted in Chemical Laboratory of Kopertis Wilayah X Padang. The research found that E. coli is more resistant to tea leaves than Salmonella sp. The minimum restriction concentrate of tea leaves extract (Camellia sinensis L.) in E. coli is 3,125\% and 0,0975\% in Salmonella sp.

lebih dari 1,5 juta orang/tahun. Diare dapat disebatkan oleh banyak faktor, seperti 1) infeksi oleh bakteri, virus atau 
parasit, 2) alergi terhadap makanan atau obat tertentu dan 3) infeksi oleh bakteri atau virus yang menyertai penyakit lain, seperti campak, infeksi telinga, infeksi tenggorokan, malaria dan lain-lain (WHO, 2000). Penyebab diare yang paling umum adalah bakteri, terutama Salmonella sp dari famili enterobacteriaceae (Anonimous, 2008). Berdasarkan keterangan dari beberapa rumah sakit untuk kasus diare akut yang terjadi di Indonesia, lebih dominan disebabkan oleh Escherichia coli yaitu antara 20 - $30 \%$ (Alfa, 1996 dalam Faulinawati, 2009).Diare yang disebabkan oleh bakteri biasanya diobati dengan member bahan yang mampu dijadikan sebagai antimikroba. Zat antimikroba yang ideal memiliki toksisitas selektif. Toksisitas selektif lebih bersifat relatif dan bukan absolut, artinya penggunaan dengan konsentrasi tertentu berbahaya bagi parasit tetapi tidak berbahaya bagi inangnya (Jawetz dkk., 1996). Mekanisme penghambatan pertumbuhan mikroorganisme oleh senyawa antimikroba dapat berlangsung melalui beberapa cara, yaitu: 1) Menganggu pembentukan dinding sel, hal ini disebabkan karena terjadinya akumulasi komponen lipofilat yang terdapat pada dinding atau membran sel sehingga menyebabkan perubahan komposisi penyusun dinding sel. Terjadinya akumulasi senyawa antimikroba dipengaruhi oleh bentuk tak terdisosiasi. Salah satu senyawa antimikroba yang menghambat sintesis dinding sel adalah penisilin. 2) Bereaksi dengan membran sel, beberapa antimikroba merusak permeabilitas membran, akibatnya terjadi kebocoran materi intraseluler, seperti senyawa phenol yang dapat mengakibatkan lisis sel dan menyebabkan denaturasi protein, menghambat pembentukan protein sitoplasma dan asam nukleat, serta menghambat ikatan ATP-ase pada membran sel. 3) Menghambat aktivitas enzim, efek senyawa antimikroba dapat menghambat kerja enzim jika antara ikatan kompleks yang menyusun struktur enzim dengan komponen senyawa antimikroba mempunyai spesifitas yang sama. Penghambatan ini dapat mengakibatkan terganggunya metabolisme sel (Ardiansyah, 2007). Komponen bioaktif dapat mengganggu pembentukan asam nukleat (RNA dan DNA), menyebabkan terganggunya transfer informasi genetik yang selanjutnya akan menginaktivasi atau merusak materi genetik sehingga terganggunya proses pembelahan sel untuk pembiakan. Kemampuan senyawa ntimikroba dalam menghambat aktivitas pertumbuhan mikroba dipengaruhi oleh beberapa faktor. Adapun faktor yang mempengaruhinya adalah: 1) Konsentrasi zat antimikroba, semakin tinggi konsentrasi bakteri yang digunakan, semakin cepat bakteri terbunuh. 2) Suhu, kenaikan suhu dapat menaikkan keefektifan suatu anti mikroba dan laju reaksi dipercepat dengan meningkatkan suhu. 3) Spesies mikroorganisme, adapun masing-masing spesies memiliki ketahanan berbedabeda terhadap antimikroba. Bakteri yang membentuk spora lebih tahan dari pada yang tidak membentuk spora. 4) Bahan organik, adanya bahan organik lain yang dapat menurunkan keefektifan zat kimia antimikroba. Bahan organik 
dapat melindungi mikroorganisme dari zat antimikroba. 5) Kadar asam (pH), mikroorganisme yang hidup pada lingkungan asam dapat dimusnahkan pada suhu yang lebih rendah dan waktu yang lebih singkat dibandingkan di lingkungan basa. Antimikroba ada yang aktif pada lingkungan asam dan ada yang aktif pada lingkungan basa dan 6) Jumlah mikroorganisme, semakin banyak jumlah sel mikroba, maka waktu perlakuan yang diberikan untuk mematikan semua mikroba akan lebih lama (Pelczar, 1988). Pemberian antibiotik dalam jangka waktu yang lama dapat menyebabkan resistensi dan akumulasi toksin dalam tubuh (Setiabudy dan Gan 1995). Begitu juga dengan pemberian antidiare dengan dosis yang tidak sesuai dapat mengakibatkan feses menjadi keras dan defekasi terhalang, sedangkan feses harusnya dikeluarkan dari tubuh karena mengandung toksin (Anonimus, 2008). Salah satu alternatif yang bisa digunakan untuk mengatasi masalah ini adalah dengan memanfaatkan bahan aktif antimikroba dari tanaman obat. Yulia (2009) sudah menguji berbagai macam sari tanaman obat yang digunakan untuk penanganan diare. Dari sekian banyak sari tanaman obat yang diujikan, didapatkan daun teh paling efektif menghambat pertumbuhan bakteri penyebab diare. Teh berkhasiat untuk mengobati sakit kepala, diare, penyubur dan menghitamkan rambut, darah tinggi dan infeksi saluran cerna. Selain itu teh juga dapat digunakan sebagai obat diabetes melitus, mencegah osteoporosis, menurunkan berat badan dan menurunkan resiko penyakit kanker
(Sutarmaji, 1994). Tanaman the mengandung berbagai jenis bahan kimia, seperti theo- bromin, theofilin, tanin, katekin, kafein, xantin, adenin, kuersetin, saponin, flavonoid dan natural fluorida. Kandungan tanin, saponin dan flavonoid yang terdapat dalam daun teh berkhasiat sebagai antimikroba. Tanin ditemukan hampir di setiap bagian dari tanaman, seperti pada kulit batang, daun dan akar (Sutarmaji, 1994). Saponin merupakan senyawa kimia yang memberikan rasa pahit pada bahan pangan nabati. Saponin dapat menghambat pertumbuhan kanker kolon dan membantu menjaga kadar kolesterol tetap normal (Suja, 2008). Saponin tidak bersifat toksik, karena tidak dapat diserap oleh usus (Muchtadi, 2005). Flavonoid merupakan salah satu golongan fenol alam yang terbesar. Flavonoid mempunyai sifat yang khas yaitu bau yang sangat tajam, dapat larut dalam air dan pelarut organik. Flavonoid dapat berperan secara langsung sebagai antibiotik karena dapat melisis sel dan menyebabkan denaturasi protein, menghambat sintesis protein dan asam nukleat, serta menghambat ikatan ATPase pada membran sel (Suja, 2008). Antimikroba yang digunakan hendaknya tidak menimbulkan efek samping serta tidak menganggu keseimbangan flora normal tubuh. Selain itu antimikroba yang digunakan harus mempunyai spectrum yang luas (broad spectrum antibiotic), tidak menimbulkan mikroorganisme resisten dan memiliki toksisitas selektif. Toksisitas selektif ini juga harus bersifat relatif dan bukan absolut, artinya pada konsentrasi tertentu dapat ditoleransi oleh inang dan sudah dapat merusak mikroba (Anonimus, 
2008). Toksisitas selektif bahan aktif antimikroba dapat diketahui dengan cara menentukan konsentrasi habat minimum (KHM). Penelitian mengenai KHM bahan aktif antimikroba dari beberapa tanaman obat telah banyak dilakukan. Adnyana (2004) meneliti KHM kulit buah duku terhadap E. coli, Shigella dysenteriae dan Salmonella typhi, dari penelitian tersebut didapatkan KHM terhadap E. coli dan S. typhi $2 \mathrm{mg} / \mathrm{ml}$ dan terhadap Shigella dysenteriae $4 \mathrm{mg} /$ ml. Selain itu Adnyana dkk. (2004) juga meneliti KHM ekstrak daging buah jambu biji putih, dari penelitian tersebut didapatkan KHM terhadap bakteri Shigella flexneri $40 \mathrm{mg} / \mathrm{ml}$, bakteri Shigella dysenteriae $30 \mathrm{mg} / \mathrm{ml}$, dan bakteri E. coli $60 \mathrm{mg} / \mathrm{ml}$. Selanjutnya (Oktafiani, 1999) meneliti KHM ekstrak jariangau dan didapatkan KHM terhadap E. coli, S. typhi dan Vibrio cholera 1,56 $\%$ serta terhadap Shigella sp. 6,25\%. Berdasarkan hasil penelitian yang sudah ada, menunjukkan bahwa konsentrasi hambat minimum (KHM) dari bahan aktif antimikroba yang dikandung tanaman belum tentu sama, maka atas dasar tersebut dilakukan penelitian dengan tujuan untuk mengetahui Konsentrasi Hambat Minimum (KHM) ekstrak daun teh (Camellia sinensis) pada bakteri Salmonella sp dan Escherichia coli.

\section{METODE PENELITIAN}

Penelitian dilaksanakan pada bulan Agustus 2010 di laboratorium Biologi STKIP PGRI Sumatera Barat Padang. Pembuatan ekstrak daun teh dilaksanakan di laboratorium Kimia Kopertis Wilayah X Padang. Jenis penelitian ini adalah penelitian eksperimen dengan data kualitatif. Perlakuan yang diberikan berupa konsentrasi ekstrak daun teh (Camellia sinensis L.). Masing-masing perlakuan diujikan untuk melihat konsentrasi hambat minimum KHM) ektrak daun teh pada bakteri Escherichia coli dan Salmonella sp serta penentuan KHM menggunakan metode dilusi dan masingmasing perlakuan dilakukan duplo. Masing-masing perlakuan tersebut adalah 1,56 \%, 3,125\%, 6,25\%, 12,5\%, $25 \%$ dan $50 \%$ untuk E. coli dan 0,0975 $\%, 0,195 \%, 0,39 \%, 0,78 \%, 1,56 \%$, $3,125 \%, 6,25 \% 12,5 \%, 25 \%$ dan $50 \%$ untuk Salmonella sp.

Urutan kerja dalam penelitian ini adalah: 1. Penyediaan daun dan ekstrak daun teh, daun teh didapat dari kebun teh Alahan Panjang dan pembuatan ekstrak daun teh (Camellia sinensis) dilakukan dilaboratorium Kimia Kopertis Wilayah $\mathrm{X}$ Padang. Daun teh dimaserasi dengan menggunakan pelarut etanol $96 \%$ selama 5 hari, sekali-kali rendaman ini diaduk. Setelah itu larutan disaring, kemudian filtrat didestilasi dengan vakum rotary avaporator.

2. Pembuatan suspense bakteri E. coli dan Salmonella sp., biakan diperoleh dari laboratorium Mikrobiologi Fakultas Kedokteran Unand dan perbanyakan dilakukan di Laboratorium Biologi STKIP PGRI Sumatera Barat dengan menggunakan mediun NA. Masingmasing bakteri Salmonella sp. dan Escherichia coli, disuspensikan ke dalam $9 \mathrm{ml}$ akuades steril sebanyak 1 ose, kemudian diencerkan dengan cara yang sama sampai kekeruhannya sama dengan 
kekeruhan larutan Mc Farland's 0,5 (10 $\mathrm{sel} / \mathrm{ml}$ ).

3. Penentuan konsentrasi hambat minimum (KHM), disiapkan sebanyak 13 buah tabung reaksi untuk E. coli dan 17 buah untuk Salmonella sp dan masing-masing diberi label, lalu dilakukan tahap kerja sebagai berikut:

a. $9 \mathrm{ml}$ ekstrak daun teh $100 \%$ dimasukkan ke dalam tabung reaksi No. 1 yang telah berisi $1 \mathrm{ml}$ akuades (90\%)

b. $8 \mathrm{ml}$ ekstrak daun teh $100 \%$ dimasukkan pada tabung No. 2 yang telah berisi $2 \mathrm{ml}$ akuades (80\%).

c. $7 \mathrm{ml}$ ekstrak daun teh $100 \%$ dimasukkan ke tabung No. 3 yang telah berisi $3 \mathrm{ml}$ akuades (70\%).

d. $6 \mathrm{ml}$ ekstrak daun teh $100 \%$ diamsukkan ke tabung No. 4 yang telah berisi $4 \mathrm{ml}$ akuades $(60 \%)$.

e. $5 \mathrm{ml}$ ekstrak daun teh $100 \%$ diamsukkan ke tabung No. 5 yang telah berisi $5 \mathrm{ml}$ akuades (50\%)

f. Tabung No. 6 sampai 10 diisi dengan $5 \mathrm{ml}$ akuades

g. $5 \mathrm{ml}$ ekstrak daun teh $50 \%$ dimasukkan ke dalam tabung No. 6 dan tabung No. 7. Selanjutnya $5 \mathrm{ml}$ suspensi dari tabung No. 7, dipindahkan ke tabung

8. Demikian seterusnya dilakukan hingga tabung No. 10 untuk E. coli dan hingga No. 14 untuk Salmonella sp, sehingga diperoleh konsentrasi sari daun teh berturut-turut sebagai berikut: Tabung No. $6=$ Konsentrasi $25 \%$, No. 7 $=$ Konsentrasi 12,5 \%, No. $8=$ Konsentrasi 6,25\%, No. $9=$
Konsentrasi 3,125 \%, No. $10=$ Konsentrasi 1,56 \%. Untuk Salmonella sp dilakukan penurunan konsentrasi sampai $0,0975 \%$ (Tabung No. $11=$ konsentrasi $0,78 \%$, No. $12=$ konsentrasi $0,39 \%$, No. $13=$ konsentrasi $0,195 \%$ dan No. $14=$ konsentrasi 0,0975 \%)

h. Tabung No. 11 diisi $10 \mathrm{ml}$ suspensi bakteri, tabung No. 12 diisi amphicillin $10 \%$ (kontrol antibiotik), tabung No. 13 diisi $3 \mathrm{ml}$ ekstrak teh $100 \%$ (kontrol ekstrak) untuk bakteri E. coli sedangkan untuk Salmonella sp masing-masing konsentrasi perlakuan tersebut dimasukkan ke tabung reaksi No. 15, 16 dan 17.

i. Disiapkan 13 dan 17 cawan petri, masing-masingnya diisi dengan $9 \mathrm{ml}$ Agar Muller Hinton (MHA) dan ditambahkan ekstrak daun teh dari tiap tabung (1-10 dan 13 untuk bakteri E. coli dan 1-14 serta 17 untuk Salmonella sp) kecuali tabung 11 dan 12 untuk E. coli serta 15 dan16 untuk Salmonella sp., lalu digoyang agar medium dan ekstrak daun teh tercampur selanjutnya biarkan membeku.

j. Setelah medium membeku, diinokulasikan $2 \square 1$ suspensi bakteri dengan kerapatan $107 \mathrm{sel} / \mathrm{ml}$ pada masing-masing cawan petri dan diratakan dengan drill glass. Setiap pengenceran ditanam secara duplo dan diinkubasi pada suhu 37o C selama 24 jam. 4. Pengamatan, pengamatan dilakukan dengan melihat pertumbuhan koloni bakteri pada medium Agar Muller Hinton dan pertumbuhan bakteri dinyatakan: 
(-) Jika terdapat $<10$ koloni bakteri dalam petri.

(+) Jika terdapat > 10 koloni bakteri dalam petri.

Dimana koloni dihitung 1 (satu) jika menyatu. Kontrol dinyatakan (+) bila bakteri tumbuh padat atau penuh, artinya menyebar sangat rapat di dalam petri sehingga sulit untuk dihitung (Mira dkk., 2004). 5. Analisis data, data dianalisis secara kualitatif dengan melihat Konsentrasi Hambat Minimum (KHM) ekstrak daun teh (Camellia sinensis) pada bakteri.

\section{HASIL DAN PEMBAHASAN}

Konsentrasi Hambat Minimum (KHM) ekstrak daun teh terhadap pertumbuhan Escherichia coli dapat dilihat pada Tabel 1 dan KHM ekstrak daun teh terhadap pertumbuhan Salmonella sp.dapat dilihat pada Tabel 2.

\begin{tabular}{|c|c|c|c|c|c|}
\multirow{2}{*}{ Tabel 1. KHM ekstrak daun teh (Camellia sinensis) terhadap Escherichiacoli } & \multirow{2}{*}{\begin{tabular}{c} 
KHM \\
\multirow{2}{*}{ Konsentrasi $\%$}
\end{tabular}} \\
\cline { 2 - 5 } & \multicolumn{4}{|c|}{ Petri } \\
\cline { 2 - 5 } & Jml Koloni & Hasil & Jml Koloni & Hasil & \\
\hline $50 \%$ & 0 & - & 0 & - & \\
\hline $25 \%$ & 0 & - & 0 & - & \multirow{3}{*}{$3,125 \%$} \\
\hline $12,5 \%$ & 0 & - & 0 & - & \\
\hline $6,25 \%$ & 0 & - & 0 & - & \\
\hline $3,125 \%$ & 0 & - & 0 & - \\
\hline $1,56 \%$ & 70 & + & 200 & + & \\
\hline
\end{tabular}

Dari Tabel 1 dapat dilihat Konsentrasi Hambat Minimum (KHM) ekstrak daun teh terhadap pertumbuhan Escherichia coli adalah 3,125\%.

\begin{tabular}{|c|c|c|c|c|c|}
\hline \multirow{3}{*}{$\begin{array}{c}\text { Konsentrasi } \\
\%\end{array}$} & \multicolumn{4}{|c|}{ 'Petrí' } & \multirow{3}{*}{$\begin{array}{c}\text { KHM } \\
(\%)\end{array}$} \\
\hline & \multicolumn{2}{|c|}{1} & \multicolumn{2}{|c|}{2} & \\
\hline & Ekoloni & Hasil & ¿koloni & Hasil & \\
\hline $50 \%$ & 0 & - & 0 & - & \\
\hline $25 \%$ & 0 & - & 0 & - & \\
\hline $12,5 \%$ & 0 & - & 0 & - & \\
\hline $6,25 \%$ & 0 & - & 0 & - & \\
\hline $3,125 \%$ & 0 & - & 0 & - & \\
\hline $1,56 \%$ & 0 & - & 0 & - & $0,195 \%$ \\
\hline $0,78 \%$ & 0 & - & 0 & - & \\
\hline
\end{tabular}

Tabel 2 dapat dilihat KHM ekstrak daun teh terhadap pertumbuhan Salmonella sp. adalah 0,195 \%, hal ini didasarkan tidak adanya ditemukan koloni pada perlakuan MHA + esktrak daun teh $0,195 \%$, namun jika dilihat lebih lanjut KHM ini bisa diturunkan dengan melakukan penurunan konsentrasi dari konsentrasi 0,195\%. Hal ini didasari oleh pendapat Mira dkk. (2004) adapun pertumbuhan bakteri dinyatakan negatif (-) jika jumlah koloni bakteri dalam petri < 10 koloni dan positif (+) jika jumlah koloni bakteri dalam petri $>10$ koloni. Berdasarkan hal ini Konsentrasi Hambat Minimum (KHM) ekstrak daun the terhadap pertumbuhan Salmonella sp dapat diturunkan menjadi 0,0975\%. Dari hasil yang didapatkan, dapat dilihat bahwa ekstrak daun teh mampu menghambat pertumbuhan E. coli dan Salmonella sp. Hal ini disebabkan karena daun teh memiliki konsentrasi bahan aktif antimikroba yang lebih tinggi dibandingkan dengan tanaman obat lainnya. Jika dilihat dari komposisi bahan aktif antimikroba yang dikandung, daun teh memiliki suatu bahan aktif antimikroba yang tidak dimiliki oleh tanaman obat lain, yaitu katekin. Senyawa katekin pada teh bersifat antibakteri dan antidiare (Sutarmaji, 1994). Mekanisme kerja bahan-bahan aktif yang terdapat pada daun teh dalam 
menghambat pertumbuhan bakteri E. coli dan Salmonella $\mathrm{sp}$ dapat terjadi melalui berbagai cara dan antar bahan aktif memiliki mekanisme yang berbeda. Seperti 1) flavonoid, melisis sel bakteri, menyebabkan denaturasi protein, menghambat pembentukan protein, sitoplasma dan asam nukleat serta menghambat ikatan ATP-ase pada membran sel. 2) Saponin, merubah permeabilitas membran sel. Dan 3) Tanin, mempresipitasi protein, inaktivasi enzim, destruksi atau inaktivasi fungsi materi genetik (Sundari, 1996). Dari Tabel 1 dan 2 dapat dilihat bahwa KHM ekstrak daun teh untuk E. coli $(3,125 \%)$ jauh lebih tinggi dari Salmonella sp. $(0,0975 \%)$. Hal ini menunjukkan E. coli lebih resisten terhadap ekstrak daun teh dibandingkan. Salmonella sp. Perbedaan ini disebabkan karena E. coli mempunyai dinding sel yang lebih tebal dari Salmonella sp, adapun dinding sel dari E. coli dilapisi oleh kapsul yang tebal dan berfungsi melindungi selnya dari zat-zat yang bersifat toksit. E. coli memiliki kapsul berupa lapisan lendir yang mengelilingi dinding sel bakteri. Kapsul berfungsi melindungi sel dari zat toksik yang ada di sekitarnya (Pelczar, 1988). KHM ekstrak daun teh terhadap coli dan Salmonella sp. yang didapatkan kecil, hal ini membuktikan kalau aktivitas antimikroba pada ekstrak daun teh tinggi. Pernyataan ini didasarkan pada hasil yang didapat dari penelitianpenelitian KHM beberapa ekstrak tumbuhan lain sebelumnya diperoleh konsentrasi yang tinggi. Seperti KHM ekstrak daun tanjung (Mimusops elengi L.) terhadap Salmonella thypi 6,25\% (Poeloengan, 2006). KHM ekstrak etanol buah adas (Feoniculum vulgare Mill) dan ekstrak kulit batang pulasari (Alyxia reinwardtii BL.) terhadap Escherichia coli, $7 \%$ dan $8 \%$ (Yustina dkk, 2006). KHM ekstrak buah pare (Momordica charantia) terhadap Escherichia coli 70 $\%$ dan terhadap Salmonella sp. $12,5 \%$

\section{KESIMPULAN}

Dari penelitian yang telah dilakukan dapat disimpulkan bahwa Konsentrasi Hambat Minimum (KHM) ekstrak daun teh pada E. coli adalah $3,125 \%$ dan Salmonella sp. adalah $0,0975 \%$. Daya hambat ekstrak daun teh terhadap Salmonella sp. lebih tinggi dibandingkan E. coli.

\section{DAFTAR PUSTAKA}

Adnyana, I., Elin Y., Joseph I.S., Neng F.K., Muhammad I. 2004. Efek Esktrak Daun Jambu Biji Daging Buah Putih dan Jambu Biji Daging Buah Merah Sebagai Antidiare. Acta Pharmaceutica Indonesia Vol. XXX (1); 2004. Hlm. 1927.http://acta.fa.itb.ac.id/pdf_dir/is sue_29_1_3.pdf (Diakses 25 Oktober 2010.

Adnyana. 2004. Uji Aktivitas Antibakteri Penyebab Diare Ekstrak Etanol Daun Beackea frustescens L. aun oleus antropurpureus Benth, Kulit Buah Lansium demosticum Corr. Dan Daun Plumbao zeylanica L. Skripsi http://bahanalam.fa.itb.ac.id/detail. php?id=116. (Diakses 25 Oktober 2010.

Anonimous. 2008). Aktivitas Antimikroba dan Ekstrak 
http://www.medicafarma.blogspot. com/2008/11/Aktivitasantimikroba dan ekstraksi.html. Diakses 28 Oktober 2010).

Ardiansyah. 2007. Antimikroba dari Tumbuhan (Bagian Kedua). http://www.beritaiptek.com/zberita beritaiptek-2007-06-09-

Antimikrobadari-Tumbuhan-(Bagian-

Kedua).shtml. (Diakses 25 Oktober 2010).

Faulinawati. 2009. Konsentrasi Hambat Minimum (KHM) Ekstrak Buah Pare (Momordica Charantia) Terhadap Bakteri Penyebab Diare Secara In Vitro. Jurusan Biologi FMIPA, Padang. UNP.

Jawetz, Melnick \& Addelberg's. 2005. Mikrobiologi Kedokteran. Jakarta: Salemba Medika.

Mira, S., Suharti, R.Utji, Agus S., Tertia H.dan Aidilfiet. 2004. Standar Operating Prosedur (SOP) Pemeriksaan mikrobiologi Klinik. Laboratorium Mikrobiologi Klinik. Fakultas Kedokteran Universitas Indonesia. Jakarta.

Muchtadi, D. 2005. Dedak Padi Mencegah Penyakit Jantung Koroner.

Departemen of Food and Technology. IPB Info Teknologi Pangan.

http://web.ipb.ac.id/tpg/de/pubde_ntrtnhl th_dedakpadi.php. (Diakses 25 Oktober 2010).

Pelczar, Mj dan EJS, Chan. 1988. Dasardasar Mikrobiologi Jilid 2. Jakarta: UI Press.
Poeloengan. 2006. Penampisan Kandungan Kimia dan Uji Daya Antibakteri Ekstrak Daun Tanjung (Mimosops elengi L.) Terhadap Salmonella thypi dan Shigella Boydii. Prosiding Seminar Teknologi Peternakan danVeteriner.

http://peternakan.litbang.deptan.go .id/?=531. (Diakses 31 Oktober 2010.

Setiabudy dan Gan, 1995. Farmakologi dan Terapi. Fakultas Kedokteran Universitas Indonesia. Jakarta.

Suja, I. (2008). Meningkatkan Kesehatan Fisik dan Spritual Melalui Konsumsi

Makanan Satwika. Sambungan WHD. No. 499. http://www.parisada. org/indekx.php?option=com_conte nt\&task=view\&id=931\&itemid=2 . (Diaksed 31 Oktober 2010).

Sundari, D. Padmawanita, K. dan Ruslan, K. 1996. Analisis Fitokimia Ekstrak Etanol Daging Buah Pare (Momordica charantia L.) Tesis Sekolah Farmasi ITB. http//bahan-alam-fa.itb.ac.id/ detail.php?id=132.

Sutarmaji, A. 1994. Tanaman Obat Indonesia.

http://www.iptek.net.id/ind/pd_tan obat/view.php?mnu=2\&id=159. (Diakses 25 September 2010).

WHO. 2000. Tatalaksana Demam Thypoid.

http://jujuku.wordpress.com/2009/ 11/25/tatalaksana-demam-thypoid/ (Diakses 25 September 2010). 
Yulia, S. (2009). Daya Hambat Sari

Tanaman Obat Terhadap

Pertumbuhan Escherichia coli

Penyebab Diare. Jurusan Biologi

FMIPA, Padang; UNP. 